RESEARCH ARTICLE

\title{
Corticolous lichen diversity, a potential indicator for monitoring air pollution in tropics
}

\author{
A.N.P.M. Attanayaka ${ }^{1}$ and S. Chandrani Wijeyaratne ${ }^{2^{*}}$ \\ ${ }^{1}$ No. 103, Keppetipola Road, Badulla. \\ ${ }^{2}$ Department of Botany, Faculty of Applied Sciences, University of Sri Jayewardenepura, Gangodawila, Nugegoda.
}

Revised: 22 December 2012; Accepted: 21 April 2013

\begin{abstract}
As information on lichen diversity and air quality in tropical ecosystems are limited, attempts were made in this study to correlate the distribution and diversity of corticolous (tree bark colonizing) lichens in the Western Province of Sri Lanka. The major source of air pollution in the study area was vehicular emissions. Thirty one sites located on six transects diverging from the Colombo City were selected for this purpose. Eight trees representing three species (Cocos nucifera, Mangifera indica and Artocarpus heterophyllus) within each site $\left(1 \mathrm{~km}^{2}\right)$ were chosen for the study. The coverage and frequency of corticolous lichens found on the selected trees were recorded by using $250 \mathrm{~cm}^{2}$ grids. After studying their morphology, anatomy, reproductive structures and chemistry, the lichens were identified using taxonomic keys. In addition, land use pattern, traffic density, $\mathrm{pH}$ of the substrates and exposure levels of the bark of these trees to light were also recorded. Ambient $\mathrm{SO}_{2}$ and $\mathrm{NO}_{2}$ levels at each site were determined using passive samplers having filter pads coated with the absorbing reagents ethylene glycol and acetone for $\mathrm{SO}_{2}$, and $\mathrm{NaI}, \mathrm{NaOH}$ and ethylene glycol for $\mathrm{NO}_{2}$. Data were analyzed statistically using the mean comparison, correlation coefficient and principal component analysis to investigate the relationship between the diversity of lichens and environmental parameters. Lichen diversity data collected on selected trees were used to formulate the index of atmospheric purity (IAP). A negative correlation was found to exist between the lichen diversity expressed as IAP and the concentrations of $\mathrm{SO}_{2}$ and $\mathrm{NO}_{2}$ levels in the study sites. These results revealed that corticolous lichens have the potential to be used as indicators of air quality monitoring in a tropical environment as well.
\end{abstract}

Keywords: Air pollution in tropics, corticolous lichens, index of atmospheric purity (IAP).

\section{INTRODUCTION}

In the recent past, the problem of air pollution was mainly confined to developed countries, but currently it has become a major global environmental issue mainly due to the increased fossil fuel consumption and the lack of planning to implement mitigation measures to control air pollution. Air pollution monitoring is indispensable for data compilation in order to develop standards, source reduction and for general air pollution control etc. Monitoring and quantification of diverse atmospheric pollutants are usually done by means of physicochemical methods (Matusmoto \& Mizoguchi, 1995). Although these methods provide accurate and reliable data, the instruments required for such assays are expensive and cannot provide monitoring at high intensity levels across large areas at different locations. Moreover, physicochemical methods in spite of their accuracy, fail to provide information on possible effects of various pollutants on living organisms (Awang, 1995). On the contrary, the concept of biomonitoring provides an assessment of the effects of pollutants and other environmental changes on the biotic components of ecosystems (Nimis \& Purvis, 2002) and is useful since the nature and impact of environmental pollutants are also constantly changing. If organisms are to be used to monitor air pollution levels, it is necessary to know what levels and which gaseous pollutants are damaging particular organisms (Richardson, 1988). Thus, to understand the nature and effects of pollutants on living organisms, it is imperative to use plants that are claimed to have some biomonitoring potential.

Studies done by Nylander (1866) and Ferry et al. (1973) demonstrated that among various bio-indicators, lichens could be regarded as a better group of organisms for air pollution monitoring in temperate environments. In terrestrial environments, probably epiphytic lichens are the most widely used biomonitors (Nimis et al., 2002), which can detect and monitor numerous pollutants 
such as $\mathrm{SO}_{2}$, $\mathrm{HF}$, various metals, nitrogen deposits and radionuclides. They can be used as bioindicators, bioaccumulators and ecological indicators, where the approaches vary in terms of biological organization from individual species to species associations and lichen communities (Gombert et al., 2005; Nimis et al., 2005). The first systematic lichen mapping was conducted by Sernander in Stockholm when disappearance of lichens from cities was recognized (Seaward, 1993). Later, Hawksworth and Rose (1970) developed a semi quantitative scale for the forests in the UK, relating the occurrence of approximately 50 lichen species, on moderately acidic bark substrates to a range of mean winter $\mathrm{SO}_{2}$ measurements. To assess air pollution levels using lichen diversity, De Sloover and Le Blanc (1968) developed the index of atmospheric purity (IAP). The IAP values are based on their coverage and ecological index: the mean number of companion species that coexist with each species. A revised version of the IAP was later developed by the same authors ( Le Blanc \& De Sloover, 1970) and is used in this study.

In temperate countries, it has been very well demonstrated that environmental factors such as clean air has a direct bearing on lichen diversity and distribution (Hawksworth \& Rose, 1970). However, in tropical climates limited information is available with regard to lichen diversity and air quality. Lack of knowledge on lichen taxonomy and the inconspicuous nature of lichens when compared to other plants could be the reasons for not making much use of them in air pollution monitoring in the tropics. As earlier studies on lichens of Sri Lanka had been confined mainly to lichen systematics (Leighton, 1869; Nylander, 1900; Kurokawa \& Mineta, 1966; Kurokawa, 1973; Hale, 1980, 1981), there are no previous data available on relating responses of lichens to air pollution. Thus in the present study, attempts were made to assess the use of corticolous lichens as a potential biomonitoring tool in the estimation of air pollution in the Western Province, which is the most populated and polluted province in Sri Lanka. For this purpose, data on concentrations of $\mathrm{SO}_{2}$ and $\mathrm{NO}_{2}$ in the air and the diversity and distribution of lichens in selected sites were recorded simultaneously and then correlated. In addition, the sources of $\mathrm{SO}_{2}$ and $\mathrm{NO}_{2}$, especially the traffic density and other microclimatic factors that could influence lichen distribution such as land use pattern, $\mathrm{pH}$ of the substrate, and exposure to light were also considered.

\section{METHODS AND MATERIALS}

\section{Study area}

Study area was confined to the Western Province of Sri Lanka, which consists of three districts, Colombo,
Gampaha and Kalutara. The mean annual rainfall in this region, received mainly from the two monsoons; Southwest and Northeast, ranges from $2500 \mathrm{~mm}$ to $5000 \mathrm{~mm}$. Inter-monsoonal rainfall also makes a substantial contribution to the mean annual rainfall of this region. The mean temperature is $30{ }^{\circ} \mathrm{C}$, while the mean relative humidity is about $74 \%$. The elevation of the region varies from sea-level to $300 \mathrm{~m}$.

Study sites: Thirty-one sites falling on six transects starting from the Colombo City to suburbs up to a distance of $50 \mathrm{~km}$ were demarcated. The Colombo City site was considered as the first site (CC) on all transects (Figure 1). The area of each site was $1 \mathrm{~km}^{2}$ and all the sites were located within the same climatic zone. This study was conducted from March 2001 to December 2003.

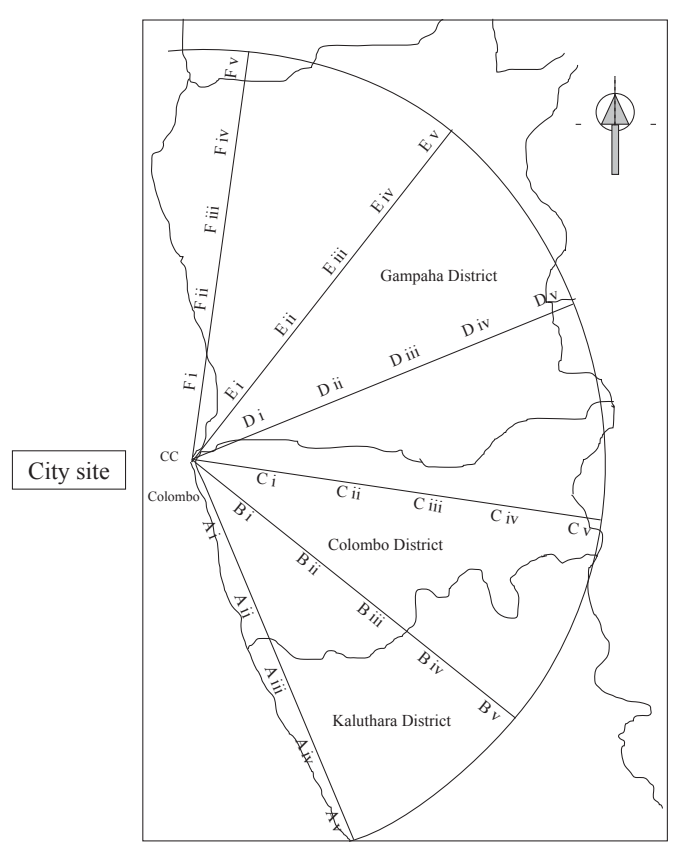

Figure 1: Map of the surveyed area showing locations of the 31 sites

\section{Selection of sample trees}

In each site, 8 trees ( 3 trees from $C$. nucifera, 3 from $M$. indica, 2 from $A$. heterophyllus) with a minimum of $30 \mathrm{~cm}$ diameter at breast height $(\mathrm{DBH})$ were randomly selected for sampling lichens. These trees were specifically selected as they were the common tree species found in the area under study.

\section{Lichen sampling}

The coverage and frequency of lichens on vertical trees having a DBH greater than $30 \mathrm{~cm}$ were recorded by placing a $250 \mathrm{~cm}^{2}(25 \mathrm{~cm} \times 10 \mathrm{~cm})$ quadrate randomly 
at four places above a height of $0.5 \mathrm{~m}$ from the ground up to $1.5 \mathrm{~m}$ height of the bole of each tree, according to VDI (Verein Deutscher Ingenieure) guideline (1995). The number of lichen species found within the grid and the number of grid units in which a particular species was found were estimated. Lichens with a diameter less than $3 \mathrm{~mm}$ were not recorded.

Identification of lichens: The lichens were identified using taxonomic keys (Awasthi, 1988; Awasthi, 1991; Sipman, 1996) after studying their morphological, anatomical and chemical characters. Most of the lichens were identified only up to the generic level.

Determination of lichen diversity index at different sites: Lichen diversity of each site was determined using Shannon's diversity index (Batten, 1976).

$$
H^{\prime}=-\sum p_{i}\left(\log p_{i}\right)
$$

Where,

$$
\begin{aligned}
& H^{\prime}=\text { Diversity } \\
& p_{i}=\text { the proportional abundance of the } i^{\text {th }} \text { species }
\end{aligned}
$$

The sites were categorized into four classes according to the calculated values of lichen diversity indices: sites with the diversity index between 0.80 and 0.89 were categorized as low lichen diversity class; between 0.90 and 0.99 as moderate lichen diversity class; between 1.00 and 1.09 as high lichen diversity class and values greater or higher than 1.10 as very high lichen diversity class.

\section{Land-use pattern of sites}

The sites selected for the study were categorized into four classes according to the land use patterns observed in the sites: industrial, highly disturbed, moderately disturbed and sparely disturbed areas, The industrial category was defined as having various industries, which may or may not make a contribution to air pollution in addition to the disturbance of vegetation; highly disturbed category had more than $65 \%$ of the vegetation in the area disturbed due to buildings; moderately disturbed areas were identified as having $65-35 \%$ of the vegetation in the area disturbed; sparely disturbed category had less than $35 \%$ of the vegetation disturbed due to buildings or any other man-made structures.

\section{Recording of traffic densities of sites}

All the sites were categorized into four groups ranging from $1-4$, as high traffic, moderate traffic, low traffic and very low traffic based on the proximity of a particular site to a main road, secondary road with high traffic, secondary road with less traffic, minor road with very little traffic, respectively.

\section{Exposure to light}

Light intensity at each site was measured at the time of sampling using a lux meter (Digital model 401025) and arrived at a qualitative scheme of classification as indicated below.

\section{Light intensity in Lux (quantitative)}

$$
\begin{aligned}
& 1500 \text { Lux } \\
& <1500-1200 \text { Lux } \\
& <1200 \text { Lux }
\end{aligned}
$$

\section{Exposure (qualitative)}

Sunny (1)

Semi shade (2)

Shade (3)

\section{Bark pH}

Bark $\mathrm{pH}$ of all the selected trees were measured using standard electrodes after keeping the bark pieces overnight in a $25 \mathrm{mM} \mathrm{KC1}$ solution (Farmer et al., 1990).

Index of atmospheric purity: (IAP) values were calculated for each site based on the number, frequency and ecological index of epiphytic lichens found at each station, which is expressed by the formula:

$$
\mathrm{IAP}=\sum_{1}^{\mathrm{n}}(\mathrm{Q} \times f) / 10
$$

Where

$\mathrm{n}=$ Number of species recorded

$\mathrm{Q}=$ Ecological index (i.e. the average number of species, which coexisted with each species)

$f=$ Cover or frequency of each species

The ecological index of each species is defined as the mean number of companion species, which coexisted with each species or the factor of accompanying species. If a species occurs in a species - poor vegetation located in a heavily polluted areas, it will have a low number of companion species. On the contrary, those species in a less polluted areas will have a higher number of companion species (Le Blanc \& De Sloover, 1970; Dymytrova, 2009).

\section{Determination of $\mathrm{SO}_{2}$ concentrations}

Passive samplers of the 'Ogawa' type (Ogawa \& Co., USA) were used. The samplers were loaded with filter pads coated with $150 \mu \mathrm{l}$ of absorbing reagent containing triethanolamine (TEA), ethylene glycol and acetone and sealed with end caps before exposing them in the sampling site. Sampling duration was 4 wks and all the samplers were installed at a height of about $3 \mathrm{~m}$ from the ground level (Hirano \& Maeda, 1996). 
Sampling: Passive samplers were fixed to the windshields and exposed to air for a period of one month. They were removed and transferred to the laboratory for analysis. Windshields were fixed on to trees that were located away from the roadsides and other emission sources in order to prevent filter pads coming in direct contact with emissions, which in turn may give incorrect values (Hirano \& Maeda, 1996).

Analysis: The trapped $\mathrm{SO}_{2}$ was extracted into $10 \mathrm{~mL}$ of colour developing reagent (sulfamic acid $1 \mathrm{~mL}$, formaldehyde $2 \mathrm{~mL}$, pararosaniline $2 \mathrm{~mL}$ and water $5 \mathrm{~mL}$ ). After development of colour, intensity was measured using UV-visible spectrophotometer at $542 \mathrm{~nm}$ wavelength. The concentration of $\mathrm{SO}_{2}$ was then calculated from a calibration plot with known concentrations of TEA solution (Hirano \& Maeda, 1996).

\section{Determination of $\mathrm{NO}_{2}$ concentration at sites}

The same type of passive samplers and windshields were used to trap $\mathrm{NO}_{2}$. Samplers loaded with filter pads coated with $150 \mu \mathrm{L}$ of absorbing reagent containing NaI, $\mathrm{NaOH}$ and ethylene glycol were used (Hirano \& Maeda, 1996).

Sampling: Sampling procedure of $\mathrm{NO}_{2}$ was similar to that of $\mathrm{SO}_{2}$.

Analysis: The trapped $\mathrm{NO}_{2}$ was extracted into $10 \mathrm{~mL}$ of colour developing reagent(Saltzmann reagent) (Saltzman, 1954). The intensity of the colour developed was measured using UV-visible spectrophotometer at $540 \mathrm{~nm}$ wavelength. The concentration of $\mathrm{NO}_{2}$ was calculated against a calibration plot with known concentrations of sodium nitrite (Hirano \& Meada, 1996).

\section{Statistical data analysis}

To investigate the differences among sites in the study area, with respect to lichen diversity and other parameters of the sites, statistical analyses were carried out using SPSS PC-10 statistical package. One way analysis of variance (ANOVA) was carried out on the dataset and mean comparison was performed in cases where the difference was significant at $\mathrm{p} \leq 0.05$. Differences of lichen diversity indices, $\mathrm{SO}_{2}$ and $\mathrm{NO}_{2}$ concentrations and bark $\mathrm{pH}$ across the distance from the city center, different land use patterns, traffic densities and light conditions in the sites were subjected to ANOVA. In this analysis, least significant difference (LSD) was used to separate the mean values at $\mathrm{p} \leq 0.05$ level. For the purpose of testing the relationship between diversity index and other variables, correlation coefficients (Pearson Brown product movement correlation) were calculated and tested for their significance at $p \leq 0.05$. In addition, curve fittings were attempted to find the pattern in $\mathrm{SO}_{2}, \mathrm{NO}_{2}$ and IAP datasets in relation to distance of the site from the city center.

\section{RESULTS}

A total of 47 lichen genera belonging to 25 lichen families were collected from the study area and identified to generic or species level. The lichen diversity in terms of number of genera gradually increased along transects when moving away from the city (Figure 2). This phenomenon was prominent on all transects and there was a $50 \%$ increase in the number of genera in sites beyond $20 \mathrm{~km}$ distance from the city. However in the case of families, these observations clearly indicate that lichen distribution is affected by the pollutants in the air in areas close to the Colombo City.

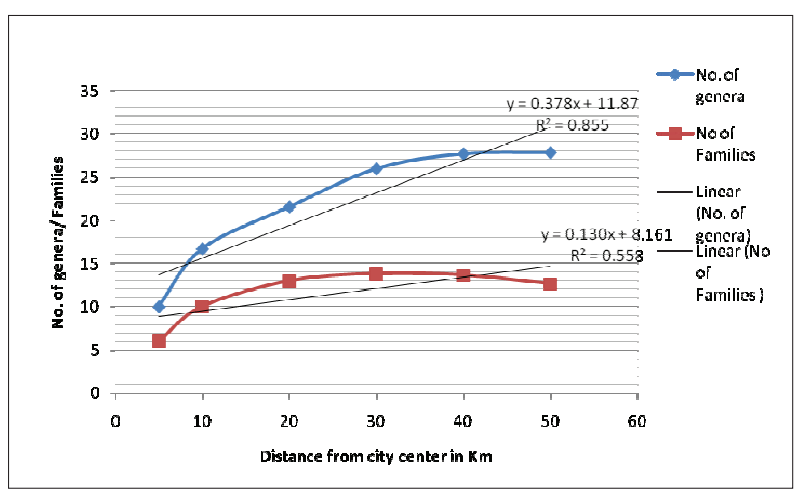

Figure 2: Change in the number of lichen families and genera in relation to distance from the city center

Table 1 shows the mean standard deviation of all the parameters measured in the study. The mean $\mathrm{SO}_{2}$ and $\mathrm{NO}_{2}$ levels changed with distance from the city. The levels of both $\mathrm{SO}_{2}$ and $\mathrm{NO}_{2}$ decreased significantly $(\mathrm{p} \leq 0.05)$ as experimental sites moved away from the city to suburbs (Table 1). Beyond $30 \mathrm{~km}$, all sites showed no apparent difference in the mean $\mathrm{SO}_{2}$ levels. The mean $\mathrm{NO}_{2}$ level showed significant difference up to $40 \mathrm{~km}$ and beyond that there was no significant difference. The highest mean $\mathrm{SO}_{2}$ and $\mathrm{NO}_{2}$ levels $\{48.35$ (0.00) ppm, 42.83 $(0.00) \mathrm{ppm}\}$, respectively, were recorded from a site in the highly disturbed area ( site-CC). The levels were significantly higher than all the other land use categories considered in the study $(\mathrm{p} \leq 0.05)$. The reported mean $\mathrm{SO}_{2}$ levels for different land use categories were significantly different from each other, while $\mathrm{NO}_{2}$ levels were not 
Table 1: Mean comparison of lichen diversity indices, $\mathrm{SO}_{2}$ and $\mathrm{NO}_{2}$ concentrations, bark pH of C. nucifera, M.indica, and A.heterophyllus and IAP indices across different land use, different traffic loads, different exposure levels of light and distance from the city center in the study area.

\begin{tabular}{|c|c|c|c|c|c|c|c|}
\hline Categories & $\mathrm{SO}_{2} \mathrm{mg} / \mathrm{m}^{3}$ & $\mathrm{NO}_{2} \mathbf{m g} / \mathrm{m}^{3}$ & $\begin{array}{l}\text { pH of } \\
\text { C. nucifera }\end{array}$ & $\begin{array}{l}\mathrm{pH} \text { of } \\
\text { M. indica }\end{array}$ & $\begin{array}{l}\text { pH of A. } \\
\text { heterophyllus }\end{array}$ & $\begin{array}{l}\text { Diversity } \\
\text { index }\end{array}$ & IAP values \\
\hline \multicolumn{8}{|l|}{ Distance } \\
\hline $5 \mathrm{~km}$ & $48.35(0.00) \mathrm{a}$ & $42.83(0.00) \mathrm{a}$ & $5.80(0.00) \mathrm{a}$ & $5.92(0.00) \mathrm{a}$ & $5.83(0.00) \mathrm{a}$ & $0.84(0.00) \mathrm{a}$ & $24.00(0) \mathrm{a}$ \\
\hline $10 \mathrm{~km}$ & $17.85(6.05) b$ & $17.81(0.76) b$ & $5.90(0.62) \mathrm{a}$ & $5.97(0.14) \mathrm{a}$ & $5.92(0.12) \mathrm{a}$ & $0.94(0.08) b$ & $44.33(4.03) b$ \\
\hline $20 \mathrm{~km}$ & $12.54(1.48) \mathrm{c}$ & $12.09(2.95) \mathrm{c}$ & $5.94(0.19) \mathrm{a}$ & $5.99(0.10) \mathrm{a}$ & $5.86(0.16) \mathrm{a}$ & $0.99(0.11) b$ & $67.33(20.76) b$ \\
\hline $30 \mathrm{~km}$ & $8.88(2.17) \mathrm{d}$ & $8.62(1.67 \mathrm{~d}$ & $6.00(0.15) b$ & $5.86(0.40) \mathrm{a}$ & $5.96(0.07) \mathrm{b}$ & $1.05(0.10) \mathrm{c}$ & $73.00(22.57) b$ \\
\hline $40 \mathrm{~km}$ & $6.55(1.17) \mathrm{d}$ & $6.26(1.45) \mathrm{e}$ & $6.07(0.05) b$ & $6.07(0.17) \mathrm{a}$ & $5.96(0.10) b$ & $1.02(0.08) \mathrm{c}$ & $83.83(17.68) b$ \\
\hline $50 \mathrm{~km}$ & $6.41(1.22) \mathrm{d}$ & $5.21(1.71) \mathrm{e}$ & $5.98(0.18) b$ & $6.09(0.12) \mathrm{a}$ & $5.98(0.06) b$ & $1.12(0.06) \mathrm{c}$ & 86.33 (18.99) b \\
\hline Total & $16.64(14.90)$ & $15.38(13.04)$ & $5.95(0.152)$ & $5.98(0.20)$ & $5.92(0.11)$ & $0.99(0.12)$ & $69.45(23.84)$ \\
\hline \multicolumn{8}{|l|}{ Land use } \\
\hline Industrial area & $13.10(0.00) \mathrm{a}$ & $9.12(0.00) \mathrm{a}$ & $6.03(0.00) \mathrm{a}$ & $6.01(0.00) \mathrm{a}$ & $5.78(0.27) \mathrm{a}$ & $0.87(0.00) \mathrm{a}$ & $24.00(0) \mathrm{a}$ \\
\hline Highly disturbed & $48.35(0.00) b$ & $42.83(0.00) b$ & $5.80(0.00) b$ & $5.92(0.00) \mathrm{a}$ & $5.83(0.00) b$ & $0.84(0.00) \mathrm{a}$ & $29.75(11.50) \mathrm{a}$ \\
\hline Moderately disturbed & $13.37(6.42) \mathrm{c}$ & $13.47(5.04) \mathrm{a}$ & $5.90(0.15) b$ & $5.93(0.28) \mathrm{a}$ & $5.92(0.12) \mathrm{c}$ & $0.99(0.09) \mathrm{c}$ & $58.09(18.11) \mathrm{b}$ \\
\hline Sparsely disturbed & $7.87(2.17) \mathrm{d}$ & $7.41(3.20) \mathrm{a}$ & $6.05(0.13) \mathrm{a}$ & $6.05(0.16) \mathrm{a}$ & $5.96(0.07) \mathrm{c}$ & $1.07(0.09) \mathrm{d}$ & $85.81(14.40) b$ \\
\hline Total & $16.65(14.90)$ & $15.38(13.04)$ & $5.95(0.15)$ & $5.98(0.20)$ & $5.92(0.11)$ & $0.99(0.12)$ & $68.74(25.02)$ \\
\hline \multicolumn{8}{|l|}{ Traffic density } \\
\hline High & $30.24(16.78) \mathrm{a}$ & $26.81(14.68) \mathrm{a}$ & $5.90(0.10) \mathrm{a}$ & $5.95(0.084) \mathrm{a}$ & $5.81(0.11) \mathrm{a}$ & $0.89(0.08) \mathrm{a}$ & $39.25(13.12) \mathrm{a}$ \\
\hline Medium & $9.32(03.60) b$ & $0.10(05.19) \mathrm{b}$ & $5.96(0.22) \mathrm{a}$ & $5.93(0.35) \mathrm{a}$ & $5.96(0.13) b$ & $1.03(0.09) \mathrm{b}$ & $68.13(23.55) b$ \\
\hline Low & $8.02(02.25) b$ & $7.82(03.19) b$ & $6.01(0.12) b$ & $6.05(0.17) b$ & $5.95(0.07) b$ & $1.06(0.09) b$ & $83.36(13.66) \mathrm{c}$ \\
\hline Very low & $5.74(00.00) b$ & $3.36(00.00) b$ & $6.09(0.00) b$ & $6.14(0.00) b$ & $5.99(0.00) b$ & $1.12(0.00) b$ & $105.00(0) \mathrm{d}$ \\
\hline Total & $16.65(14.90)$ & $15.38(13.04)$ & $5.95(0.15)$ & $5.98(0.10)$ & $5.92(0.11)$ & $0.99(0.12)$ & $68.74(25.02)$ \\
\hline \multicolumn{8}{|l|}{ Light } \\
\hline Open & $9.80(3.71) \mathrm{a}$ & $10.86(5.41) \mathrm{a}$ & $5.90(0.19) \mathrm{a}$ & $5.93(0.34) \mathrm{a}$ & $5.94(0.10) \mathrm{a}$ & $1.01(0.11) \mathrm{a}$ & $67.11(26.83) \mathrm{a}$ \\
\hline Semi-shade & $22.59(19.03) b$ & $21.03(16.34) b$ & $5.95(0.15) \mathrm{a}$ & $5.98(0.15) \mathrm{a}$ & $5.91(0.10) \mathrm{a}$ & $0.98(0.13) \mathrm{a}$ & $62.25(24.91) \mathrm{a}$ \\
\hline Shade & $10.82(6.13) \mathrm{c}$ & $7.84(4.46) \mathrm{c}$ & $5.10(0.08) b$ & $6.04(0.083) \mathrm{a}$ & $5.91(0.14) \mathrm{a}$ & $1.00(0.10) \mathrm{a}$ & $85.00(11.11) \mathrm{a}$ \\
\hline Total & $16.65(14.90)$ & $15.38(13.04)$ & $5.94(0.15)$ & $5.98(0.199)$ & $5.91(0.11)$ & $0.99(0.12)$ & $68.74(25.02)$ \\
\hline
\end{tabular}

Different letters in each category indicates that mean difference is significant at $\mathrm{p}<0.05$

significantly different except in the highly disturbed category (Table 1). The highest mean $\mathrm{SO}_{2}$ and $\mathrm{NO}_{2}$ levels of 30.24 (16.78) and 26.81(14.68) ppm, respectively were found to be related to the areas where the traffic density was high and significantly different from other areas having low traffic densities. The mean $\mathrm{SO}_{2}$ and $\mathrm{NO}_{2}$ levels varied across the three different light categories and these were significantly different among the mean values $(\mathrm{p} \leq 0.05)$.

Out of the three tree types, only the mean bark $\mathrm{pH}$ values of $C$. nucifera and A. heterophyllus showed a significant difference $(\mathrm{p} \leq 0.05)$ as the distance from the city increased. Trees in sites close to the city showed more acidic $\mathrm{pH}$ values (5.80 for C. nucifera and 5.83 for A. heterophyllus) when compared to trees in sites $30 \mathrm{~km}$ away from the city; 6.00 for C. nucifera and 5.96 for A. heterophyllus (Table 1). The bark $\mathrm{pH}$ of $C$. nucifera in the industrial area was significantly different $(p \leq 0.05)$ from the highly disturbed and moderately disturbed areas but was not different from the sparely disturbed area. The mean bark $\mathrm{pH}$ of $A$. heterophyllus in industrial area was significantly different from the bark $\mathrm{pH}$ of other land use patterns $(\mathrm{p} \leq 0.05)$. The differences in bark $\mathrm{pH}$ of A. heterophyllus in highly disturbed areas and those in the village type areas were found to be significant. However, the bark $\mathrm{pH}$ of M. indica was not significantly different under different land use types (Table 1). 
Under high and medium traffic, the bark $\mathrm{pH}$ values of C. nucifera were significantly different from the bark $\mathrm{pH}$ values under low and very low traffic densities, where the values were significantly higher (6.01 and 6.09, respectively) $(\mathrm{p} \leq 0.05)$. Similarly, bark $\mathrm{pH}$ of $M$. indica in high and medium traffic density areas were significantly different to the bark $\mathrm{pH}$ values of other traffic density areas. However, in the case of $A$. heterophyllus, only the bark $\mathrm{pH}$ in high traffic density areas was significantly different from the other high traffic density areas (Table 1). Across different light categories there was no significant difference in $\mathrm{pH}$ values except in the case of C. nucifera, which had significantly low $\mathrm{pH}$ under shade conditions.

In general, when moving away from the city center to a distance of $50 \mathrm{~km}$, the mean lichen diversity showed a significant increase $(\mathrm{p} \leq 0.05)$. The diversity index of the site located in the city was $0.84(0.00)$ and was significantly different from the rest of the sites. Highest diversity index of $1.12(0.06)$ was recorded for the site located $50 \mathrm{~km}$ away from the city (Table 1).

The diversity indices varied from 1.07 (0.09) to $0.84(0.00)$ and the highest values were recorded in the sparsely disturbed sites and the lowest values in highly disturbed sites, respectively. Lichen diversities of the sites in industrial and highly disturbed land use areas were more or less similar to each other but were significantly different from the rest of the land use areas like moderately disturbed and sparsely disturbed $(\mathrm{p} \leq 0.05)$. Lichen diversity index was significantly lower [0.89 (0.08)] in sites with high traffic density but higher in other traffic density classes (Table 1). There was no significant difference among lichen diversity values under different levels of light exposure.
The mean IAP value (24) obtained for sites in the city center was significantly different to the mean values obtained for the rest of the sites (Table 1). Data indicated that mean IAP values gradually increased when the distance from the city increased. Under different land use patterns, IAP values obtained for industrial and highly disturbed sites were different from those of the moderately and sparsely disturbed sites. The mean IAP values obtained for different traffic density categories were significantly different to each other. However in the case of different light categories, there was no significant difference in the mean IAP values.

The relationship between the lichen diversity indices, ambient $\mathrm{SO}_{2}$ and $\mathrm{NO}_{2}$ levels and bark $\mathrm{pH}$ of $C$. nucifera, $M$. indica and $A$. heterophyllus trees are shown in Table 2 .

The lichen diversity correlated negatively with both $\mathrm{SO}_{2}$ and $\mathrm{NO}_{2}$ concentrations in all the study sites. Correlation coefficient between lichen diversity and $\mathrm{NO}_{2}$ was significantly different. Conversely $\mathrm{SO}_{2}$ has a positive relationship with $\mathrm{NO}_{2}$, and the correlation coefficient showed very high significant difference at $\mathrm{p} \leq 0.05$ level.

Correlation coefficients between lichen diversity and bark $\mathrm{pH}$ of the three tree species were not significantly different. Although the bark $\mathrm{pH}$ values showed negative relationships with $\mathrm{SO}_{2}$ and $\mathrm{NO}_{2}$, only bark $\mathrm{pH}$ values of $C$. nucifera and A. heterophyllus were significantly different.

Senander termed the area with no lichens on trees as a lichen desert (Hawksworth, 2002). In the study area, there were no lichen deserts although the site in the city (CC)

Table 2. The relationship between the lichen diversity indices, $\mathrm{SO}_{2}$ and $\mathrm{NO}_{2}$ concentrations, bark $\mathrm{pH}$ of $C$. nucifera, bark $\mathrm{pH}$ of $M$. indica, and bark $\mathrm{pH}$ of $A$. heterophyllus.

\begin{tabular}{|c|c|c|c|c|c|c|}
\hline & Diversity & $\mathrm{SO}_{2}$ & $\mathrm{NO}_{2}$ & $\begin{array}{l}\text { Bark pH of } \\
\text { C.nucifera }\end{array}$ & $\begin{array}{l}\text { Bark pH of } \\
\text { M.indica }\end{array}$ & $\begin{array}{c}\text { Bark } \mathrm{pH} \text { of } \\
\text { A.heterophyllus }\end{array}$ \\
\hline Diversity & 1 & -0.32 & $-0.35^{*}$ & 0.234 & 0.20 & 0.04 \\
\hline $\mathrm{SO}_{2}$ & -0.32 & 1 & $0.92 * *$ & $-0.37 *$ & -0.10 & $-0.36^{*}$ \\
\hline $\mathrm{NO}_{2}$ & $-0.35^{*}$ & $0.92 * *$ & 1 & $-0.38 *$ & -0.12 & $-0.35^{*}$ \\
\hline Bark $\mathrm{pH}$ of C. nucifera & 0.23 & $-0.37 *$ & $-0.38^{*}$ & 1 & 0.15 & $0.48 * *$ \\
\hline Bark $\mathrm{pH}$ of $M$. indica & 0.20 & -0.10 & -0.12 & 0.15 & 1 & 0.07 \\
\hline Bark pH of A. heterophyllus & 0.04 & $-0.36^{*}$ & $-0.35^{*}$ & $0.48 * *$ & 0.07 & 1 \\
\hline
\end{tabular}

* Difference is significant at $\mathrm{p} \leq 0.05$ level 
was highly disturbed and was the most polluted site with respect to $\mathrm{SO}_{2}$ and $\mathrm{NO}_{2}$. The best fitted curves obtained for absolute values of $\mathrm{SO}_{2}$ and $\mathrm{NO}_{2}$ recorded for all sites decreased with the increase of distance of sites from the city (Figure 3 ). In both cases, concentrations decreased from the city sites to rural sparsely disturbed sites. The $\mathrm{R}^{2}$ values of the estimated parameters were 0.8463 and $0.8167(\mathrm{p} \leq 0.05)$ for $\mathrm{SO}_{2}$ and $\mathrm{NO}_{2}$, respectively.

The best fitted curve for IAP, which was computed using lichen diversity values in each site increased with distance from the city (Figure 3 ). Out of all the sites monitored, the Colombo City site gave the lowest IAP value (24). The results indicated that on all transects, the general tendency of IAP values was to increase away from the city to rural sparsely disturbed sites, but there was a variation in this relationship on different transects due to differences in microclimatic conditions in individual sites. The $\mathrm{R}^{2}$ value of the integrated curve for IAP was $0.9789(\mathrm{p} \leq 0.05)$. Further, these results very clearly revealed that a reverse correlation exists between the levels of $\mathrm{SO}_{2}$ and $\mathrm{NO}_{2}$ in the atmosphere and the IAP values.

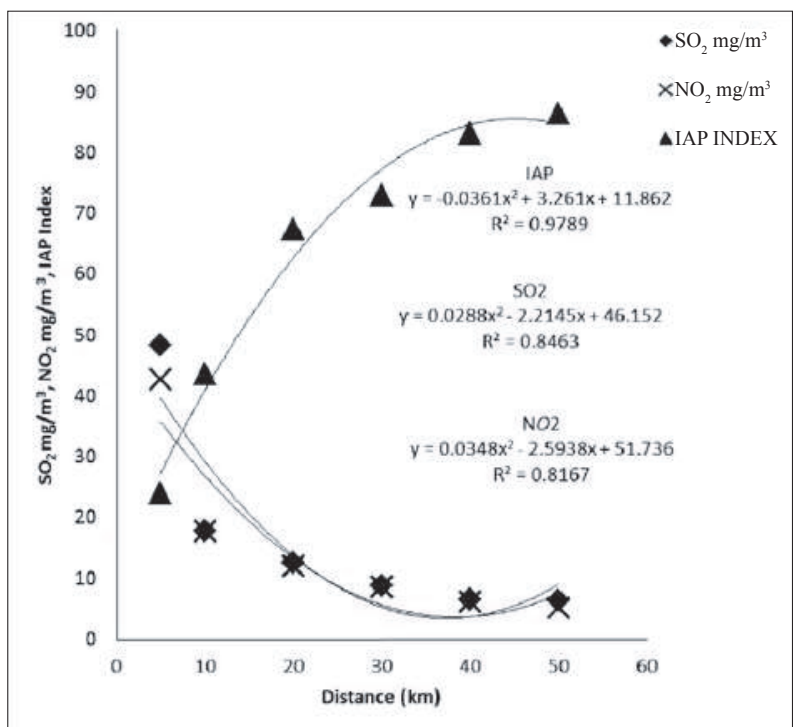

Figure 3: Best fitted curves for absolute values of $\mathrm{SO}_{2}, \mathrm{NO}_{2}$ and IAP data against distance from the city centre

\section{DISCUSSION}

This is the first study done in Sri Lanka to investigate the relationship between corticolous lichens and air pollutants. Studies done in temperate countries on lichens in relation to air pollution have demonstrated that with the increase of $\mathrm{SO}_{2}$ and $\mathrm{NO}_{2}$ levels in the atmosphere, the lichen diversity decreased gradually (Hawksworth \& Rose, 1970; Coppins, 1973; Richardson \& Puckett, 1973). In the geographic area of this study, air pollution with respect to $\mathrm{SO}_{2}$ and $\mathrm{NO}_{2}$ is mainly due to high traffic density, which is again to some extent related to land use pattern. As such, influence of all these parameters on lichen diversity could be considered concurrently. In the correlation of lichen diversity with different environmental parameters (Table 2), $\mathrm{NO}_{2}$ levels showed a significant negative relationship with lichen diversity. However, such a negative correlation was not evident with $\mathrm{SO}_{2}$ levels. This may be due to the rapid conversion of $\mathrm{SO}_{2}$ to $\mathrm{SO}_{4}^{2-}$ ions in tropical climates as suggested by Engardt and Leon (2001). According to Hien et al. (2004) sulphate ions thus produced later get deposited as particulate matter. Results of air quality studies done in the city of Colombo have shown to exceed the annual standard for PM10 stipulated by the USEPA(Jayawardana, 2003). Therefore, much lower levels of $\mathrm{SO}_{2}$ recorded in the highly disturbed site, in spite of the high traffic load in the area may be due to this conversion of $\mathrm{SO}_{2}$ to $\mathrm{SO}_{4}{ }^{2-}$ and can be the reason for the absence of a direct correlation between $\mathrm{SO}_{2}$ and lichen diversity in this study. Research carried out by Van Dobben and Ter De Brakker (1996) in the Netherlands confirmed that $\mathrm{NO}_{2}$ is negatively related to species richness although the data were confounded by $\mathrm{SO}_{2}$. Nonetheless, a number of studies have consistently shown $\mathrm{SO}_{2}$ as the major culprit affecting lichen vigour (De Sloover \& Le Blanc, 1968; Krick \& Loppi, 2002). In the present study, the highest concentration of $\mathrm{SO}_{2}$ and $\mathrm{NO}_{2}(48.35 \mu \mathrm{g} / \mathrm{m} 3$ and $42.82 \mu \mathrm{g} / \mathrm{m} 3$, respectively) were recorded from the highly disturbed site (CC) and these levels were very much lower to that in the sparsely disturbed site $\left(5.0 \mu \mathrm{g} / \mathrm{m}^{3} \mathrm{SO}_{2}, 3.6 \mu \mathrm{g} / \mathrm{m}^{3} \mathrm{NO}_{2}\right)$.

This level of air pollution in the highly disturbed Colombo City site could be mainly due to emissions from the transport sector. In 2001, at the time this research was conducted, the total vehicle fleet in Sri Lanka was close to 2,000,000 according to the Database of Registrar of Motor Vehicles (www.motortraffic.gov.lk). Several researchers have identified land transport as the main cause of pollution in urban areas of Sri Lanka including Colombo (Mallikarachchi et al., 2004, Yalegama, 2004). Further, concentrations of air pollutants in the Colombo City had been recorded higher during working days, which indicates that the vehicle fleet shuttling on the roads of Colombo City is directly responsible for poor air quality (Jayawardana \& Jayaratne, 2004). Studies done by Singh and Upreti (1989) in Lucknow, India, have attributed the decline of lichen flora in city centers to high $\mathrm{SO}_{2}$ and $\mathrm{NO}_{2}$ as a result of increased traffic. Thus, the impact of air pollution due to $\mathrm{SO}_{2}$ and $\mathrm{NO}_{2}$ levels on lichen diversity could be greater in the city site than in all the other sites away from the city. However, the above 
concentrations are very much lower when compared with the values in the scale of Hawksworth and Rose (1970) in which the above values fell close to the pure range. Although a negative correlation with lichen diversity is not apparent when $\mathrm{SO}_{2}$ alone is considered, there could be a negative correlation when the effects of $\mathrm{SO}_{2}$ and $\mathrm{NO}_{2}$ are taken together as $\mathrm{SO}_{2}$ has a significant positive correlation with $\mathrm{NO}_{2}$. A study conducted in the Colombo City by Annakkage et al. (2004) has shown that the total percentage increase of $\mathrm{NO}_{2}$ and $\mathrm{SO}_{2}$ from 1997 to 2004 was $75 \%$ and $145 \%$, respectively. However, these levels had decreased away from urban areas to rural areas (Samarakkodi et al., 2004). The air pollution studies done in Colombo with respect to $\mathrm{SO}_{2}$ and $\mathrm{NO}_{2}$ levels have shown that there is an increase in trend and $\mathrm{SO}_{2}$ level has gone above the National Standards (Jayawardana, 2003).

The highly disturbed site $(\mathrm{CC})$ and some sites very close to that (i.e. A i, A ii, B i, C i, E i) were categorized as high traffic density sites. The mean difference of lichen diversity indices between high traffic density class and other traffic density classes were significantly different, (Table 2) indicating the influence of vehicular emissions on lichen diversity. According to Gilbert (1970 b), and Mallikarachchi et al. (2004), land transport is highly correlated with ambient $\mathrm{NO}_{2}$ concentrations. The absence of significant mean difference of lichen diversity indices among other traffic density classes may be because the traffic densities recorded in the other sites were not high enough to change the environmental or substrate conditions to a level, which can affect lichen diversity. According to Seaward (1987), when moving from less polluted to a highly polluted situation, the effect of $\mathrm{SO}_{2}$ on the lichen vegetation increases exponentially so that a minor increase in $\mathrm{SO}_{2}$ would dramatically reduce the species diversity. Studies done in Chiang Mai City, Thailand have also shown that rural sites have higher diversity of lichens than urban and industrial areas (Saipunkaew et al., 2006). Thus, the progressive increase in the diversity of lichen genera observed when moving from disturbed sites in the city to sparsely disturbed rural sites (Figure 2) could be mainly due to improved air quality.

Altered land use pattern, such as development of town areas and industrial areas have also led to increase of emissions of pollutants, decline in substrate availability, and change in microhabitat conditions in an area; all of which may have an effect on the lichen diversity directly or indirectly (Jones, 1952; Barkman, 1958; LeBlanc, 1969; Batic \& Meyerhof, 1996). Absence of a significant difference in the diversity between the industrial area (land use 1) and highly disturbed area (land use 2) (Table 2) may be due to their similarity with regard to vehicular emissions. Although categorized as industrial area, there were no industries that emit air pollutants in this area, but high traffic could increase air pollution considerably. Studies have shown that there is a significant correlation between land use patterns and ambient $\mathrm{NO}_{2}$ level (Mallikaarchchi et al., 2004). These may be the possible reasons for the significant difference in lichen diversity of land use 1 and 2 when compared to land use 3 and 4. Dissimilarity in lichen diversity between land use 3 and 4 was also significant and may be due to more favourable environmental conditions or 'natural conditions' that exist in the land use 4 (sparsely disturbed) as against 'altered conditions' in land use 3 (moderately disturbed area).

Evidently, exposure to light seems to have no significant effect on the lichen diversity along all transects examined (Table 2). However, studies have shown that different lichen families have preferences either for light or shaded conditions. According to Wiesner, as stated by Smith (1921), who tested the effect of light on lichens, the need for light increases only with the lowering of the environmental temperature. As appreciable temperature fluctuations did not exist in the area that the study was conducted, light may not be a determinant factor for the distribution of lichens.

The mean values of $\mathrm{pH}$ of the bark of all three tree types showed that $\mathrm{pH}$ values have changed due to high vehicular emissions but it was remarkable in the case of C. nucifera and M. indica than A. heterophyllus (Table 2). Although bark $\mathrm{pH}$ was found to be negatively correlated with $\mathrm{SO}_{2}$ and $\mathrm{NO}_{2}$ levels, there was no significant difference between the lichen diversity and bark $\mathrm{pH}$ values of the three tree species (Table 2).

To monitor the effects of atmospheric pollutants (especially $\mathrm{SO}_{2}$ and $\mathrm{NO}_{2}$ ) on living organisms, many researchers have used the index of atmospheric purity (IAP) (De Sloover \& LeBlanc, 1968; Krick \& Loppi, 2002; Loppi, 1996). The results obtained for IAP in this study are similar to those of LeBlanc et al. (1974) that gave lower IAP values for highly disturbed city center sites while the rural areas showed higher IAP values. According to Conti and Cecchetti's (2001) categorization of air quality level based on the IAP value, the Colombo City site with an IAP value of 24 falls into Level B category (IAP $<25$ ), which means a high level of pollution. On all the other transects except transect A, sites beyond $20 \mathrm{~km}$ from the highly disturbed city center site fall into Level E category (IAP $>50$ ), which indicates a very low level of pollution. When lichens were used to monitor pollution due to geothermal emissions, similar distinct zonation with respect to IAP values [low $(<25)$ around geothermal power plants and high $(>45)$ away 
from power plants] had been observed (Loppi, 1996). Thus a high IAP value indicates a better air quality. However, in this study values of IAP obtained for all the sites along the transect A were less than 40 except the last two sites. This indicates a fairly high level of pollution in this area according to the above classification. Perhaps this may be because this transect runs parallel to a main high way and a main rail track, where the emission could be high even beyond the study area.

\section{CONCLUSION}

This study clearly revealed that air pollution in highly disturbed city sites and in some suburban sites is primarily due to vehicular emissions, which have an influence on the diversity of lichens and their distribution in the area. Further, results clearly demonstrated that lichens could be used as reliable indicators of air pollution in the tropics as well.

\section{Acknowledgement}

Authors wish to acknowledge the National Research Council of Sri Lanka (Grant No. NRC-00-31) and the University of Sri Jayewardenepura (Grant No. ASP/ 6/ $\mathrm{Re} / 2001 / 3$ ) for providing financial assistance to carry out this project. Assistance received from Ms Patricia Wolseley, Life Science Department, Natural History Museum, London in the identification of lichens is greatly acknowledged.

\section{REFERENCES}

1. Annakkage C.J., Perea M.D.C., Premasiri H.D.S. \& Samarakkody R.P. (2004). What will be the severity of the problem of air pollution in Colombo, Proceedings of the First National Symposium on Air Quality Management in Sri Lanka, 2-3 December, Air Resource Management Centre and Ministry of Environmental \& Natural Resources, Sri Lanka.

2. Awang M.B. (1995). Effects of air pollution on tropical plants, Proceedings of the International Seminar on the Simple Measuring and Evaluation Method on Air Pollution, Japan Society of Air Pollution (JSAP) and Environmental Research and Training Center (ERTC), Pathumthani, Thailand.

3. Awasthi D.D. (1988). A Key to the Macro Lichens of India, Nepal and Sri Lanka, pp. 120. Cramer, India.

4. Awasthi D.D. (1991). A Key to the Micro lichens of India, Nepal and Sri Lanka, pp. 80. Cramer, India.

5. Barkman J.J. (1958). Phytosociology and Ecology of Cryptogamic Epiphytes. Van Gorcum \& Company, Assen, The Netherlands.

6. Batic F. \& Meyerhof H. (1996). Bioindicators of air pollution by epiphytic lichens in forest decline studies in
Slovenia. Pyton 36: $85-90$.

7. Batten L.A. (1976). Birds communities of some Killarney woodlands. Proceedings of the Royal Irish Academy 76: $285-313$.

8. Conti M.E. \& Cecchetti G. (2001). Biological monitoring: lichens as bioindicators of air pollution assessment: a review. Environmental Pollution 114: 471 - 492.

9. Coppins B.J. (1973). The "Drought Hypothesis". Air Pollution and Lichens (eds. W.B. Ferry, M.S. Baddeley \& D.L. Hawksworth), pp. 124 - 142. Athlone Press, London, UK.

10. Department of Motor Traffic, Sri Lanka. www.motortraffic. gov.lk. Accessed $5^{\text {th }}$ October 2012.

11. De Sloover J. \& LeBlanc F. (1968). Mapping of atmospheric pollution on the basis of lichen sensitivity (eds. R. Misra \& B. Gopal), Proceedings of the Symposium in Recent Advances in Tropical Ecology, pp. 42 - 56, Hindu University, Varanasi, India.

12. Dymytrova L. (2009). Epiphytic lichens and bryophytes as indicators of air pollution in Kyiv city (Ukraine). Folia Cryptogamica Estonica 46: 33 - 44 .

13. Engardt M. \& Leong C.P. (2001). Regional modeling of anthropogenic sulphur in Southeast Asia. Atmospheric Environment 35:5935 - 5945.

14. Farmer A.M, Bates J.W. \& Bell J.N.N. (1990). A comparison of methods for the measurement of bark $\mathrm{pH}$. Lichenologist 22 (2): 191 - 197.

15. Ferry B.W., Baddeley M.S. \& Hawksworth D.L. (eds.) (1973). Air Pollution and Lichens. Athlone Press, London, UK.

16. Garrec J.P. \& Van Haluwyn C. (2002). Biosuveillance Ve'ge'tale de la Qualitedel'Air. Concepts, Methodes et Applications. Tec and Doc, Paris, France.

17. Gilbert O.L. (1970b). A biological scale for the estimation of sulphur dioxide pollution. New Phytologist 69: $629-634$.

18. Gombert S., Asta J. \& Seaward M.R.D. (2005). The use of autecological and environmental parameters for establishing the status of lichen vegetation in a baseline study for a longterm monitoring survey. Environmental Pollution 135(3): $501-514$.

19. Hale M.E. (1980). The lichen genus Relicina (Parmeliaceae) in India and Sri Lanka. Bryologist 83: $77-78$.

20. Hale M.E. (1981). A revision of the lichen family Thelotremataceae in Sri Lanka. Bulletin of the British Museum (Natural History), Botany Series 8: 227 - 332.

21. Hawksworth D.L. (2002). Bioindication: calibrated scales and their utility. Monitoring with Lichens - Monitoring Lichens (eds. P.L. Nimis et al.), pp. 11 - 20. Kluwer Academic Publishers, The Netherlands.

22. Hawksworth D.L. \& Rose F. (1970). Qualitative scale for estimating sulphur dioxide air pollution in England and Wales using epiphytic lichens. Nature 227: 145 - 148.

23. Hien P.D., Bac V.T. \& Thinh N.T.H. (2004). PMF receptor modeling of fine and coarse PM10 in air masses governing monsoon conditions in Hanoi, Northern Vietnam. Atmospheric Environment 38: 189 - 201.

24. Hirano K. \& Maeda H. (1996), Monitoring methods of $\mathrm{NO}_{2}$, and $\mathrm{SO}_{2}$ in ambient air using a diffusion sampler. 
Yokohama City Research Institute for Environmental Science, Yokohama, Japan.

25. Jayawardana K.G.S. (2003). Trends of air quality in the city of Colombo. Proceedings of the $59^{\text {th }}$ Annual Sessions of the Sri Lanka Association for the Advancement of Science, Colombo.

26. Jayawardene K.G.S. \& Jayaratne R.N.R. (2004). What Colombo's air quality tell us. Proceedings of the First National Symposium on Air Quality Management in Sri Lanka, 2-3 December, Air Resource Management Centre and Ministry of Environment and Natural Resources, Sri Lanka.

27. Jones E.W. (1952). Some observations on the lichen flora of tree boles with special reference to the effect of smoke. Reviews of Bryology-Lichenology 21: $96-115$.

28. Krick R. \& Loppi S. (2002). The IAP Approach. Monitoring with Lichens - Monitoring Lichens (eds. P.L. Nimis, C. Scheidegger \& P.A. Wolseley), pp. 21 - 37. Kluwer Academic Publishers, The Netherlands.

29. Kurokawa S. \& Mineta M. (1966). Enumeration of Parmelia of Ceylon. Annual Report of the Noto Marine Laboratory. University of Kanazawa, Kanazawa, Japan.

30. Kurokawa S. (1973). Supplementary notes on the genus Anapitichia. Journal of Hattori Botanical Laboratory 37: $563-607$.

31. LeBlanc F. \& De Sloover J. (1970). Relation between industrialization and the distribution and growth of epiphytic lichens and mosses in Montreal. Canadian Journal of Botany 48: 1485 - 1496.

32. LeBlanc F., Robitaille G. \& Rao D. (1974). Biological response of lichen and Bryophytes to environmental pollution in the Murdochville Copper mines area, Quebec. Journal of Hattori Botanical Laboratory 38: 405 - 433.

33. Leighton W.A. (1869). The lichens of Ceylon collected by G.H.K. Thwaites. Transactions of the Linnean Society London 27: $161-185$.

34. Loppi S. (1996). Lichens as bioindicators of geothermal air pollution in Central Italy. The Bryologist 99(1): $41-48$.

35. Mallikaarchchi B.S., Manawadu L. \& Samarakkody R.P. (2004). Identification of air pollution potential areas and spatial pattern of the City of Colombo- Applying GIS, Proceedings of the First National Symposium on Air Resources Management in Sri Lanka 2-3 December, Air Resource Management Centre and Ministry of Environment and Natural Resources, Sri Lanka.

36. Matusmoto M. \& Mizoguchi T. (1995). A simple and simultaneous measurement method of sulphur dioxide in atmosphere using molecular diffusion sampler, International Seminar on the Simple Measuring and Evaluation Method on Air Pollution, Japan Society of Air Pollution (JSAP) and Environmental Research and Training Center (ERTC), Pathumthani, Thailand.

37. Nimis P.L. \& Purvis (2002). Monitoring lichens as indicators of pollution. Monitoring with Lichens - Monitoring Lichens (eds. P.L. Nimis, C. Scheidegger \& P. A. Wolseley), pp. 7 10. Kluwer Academic Publishers, The Netherlands.

38. Nimis P.L., Scheidegger C. \& Wolseley P.A. (2002). Monitoring with Lichens - Monitoring Lichens (eds. P.L.
Nimis, C. Scheidegger \& P. A. Wolseley), pp. 1 - 4. Kluwer Academic Publishers, The Netherlands.

39. Nylander W. (1866). Les lichens du Jardin de Luxembourg. Bulletin of the Society of Botany, France 13: 364 - 372.

40. Nylander W. (1900). Lichenes Ceylonenses. Acta Societatis Scietiarum Fennicae 26(10): 1 - 26.

41. Richardson D.H.S. (1988). Understanding the pollution sensitivity of lichens. Botanical Journal of the Linnean Society 96: $31-43$.

42. Richardson D.H.S. \& Puckett K.J. (1973). Sulphur dioxide and photosynthesis in lichens. Air Pollution and Lichens (eds. B.W. Ferry, M.S. Baddeley \& D.L. Hawksworth), pp. 283 - 298. University of Toronto Press, University of Toronto, Canada.

43. Saipunkaew W., Wolseley P.A., Chimonides P.J. \& Boonpragob K. (2006). Epiphytic macro-lichens as indicators of environment alteration in Northern Thailand. Environmental Pollution 146: 366 - 374.

44. Saltzman B.E. (1954). Colorimetric microdetermination of Nitrogen dioxide in the atmosphere. Analytical Chemistry 26 (12): 1949 - 1955.

45. Samarakkodi R.P.H.D.S., Annakkage C.J. \& Basnayaka G.B.M.A. (2004). Identification of critical and shrinking areas in Colombo by means of spatial air quality monitoring, Proceedings of the First National Symposium on Air Quality Management in Sri Lanka, 2-3 December, Air Resource Management Centre and Ministry of Environment and Natural Resources, Sri Lanka.

46. Seaward M.R.D. (1987). Effects of quantitative and qualitative changesin air pollution on ecological and geographical performance of lichens. The Effects of Atmospheric Pollutants on Forests, Wetlands and Agricultural Ecosystems (eds. T. Hutchinson \& K.M. Meema), pp. 439 - 450. Spring -Verlag, Berlin, Germany.

47. Seaward M.R.D. (1993). Lichens and sulphur dioxide air pollution: Field Studies. Environmental Reviews 1:73-91.

48. Singh A. \& Upreti D.K. (1989). Lichen flora of Lucknow with special reference to its historical Monuments (eds. O.P. Agrawal \& S. Dhawn), Proceedings of the International Conference on Bio-deterioration of Cultural Property, p. 2925.

49. Sipman H. (1996). Key to the Lichen Genera of the Guianas. Botanical Museum, Berlin-Dahlem, Germany.

50. Smith A.L. (1921). Lichens, pp. 240 - 244. Cambridge University Press, London, UK.

51. Van Dobben H.F. \& Ter De Brakker J.F. (1969). Ranking of epiphytic lichen sensitivity to air pollution using survey data : a comparison of indicator scales. Lichenologist 25: $27-31$.

52. Verein Deutscher Ingenieure (VDI) (1995). Mapping of lichens for assessment of air quality VDI 799-1. VDI Handbuch Reinhaltung de Luft, pp. 1 - 27.

53. Yalegama S.S.B. (2004). Impact of emission standards on particulate pollution from diesel vehicles, Proceedings of the First National Symposium on Air Quality Management in Sri Lanka, 2-3 December, Air Resource Management Centre and Ministry of Environment and Natural Resources, Sri Lanka. 